\title{
FAKTOR PENENTU KINERJA PEGAWAI PADA DINAS PERDAGANGAN KABUPATEN MAMUJU
}

\section{Lina Mariana}

Politeknik Informatika Nasional

Email: linamariana90@yahoo.co.id

\begin{abstract}
The study aims to determine and analyze the effect of employee competence on employee performance in the Mamuju district trade service, analyze the influence of work culture on the performance of the Mamuju district trade service employee. The research approach is quantitative descriptive with a sample of 40 respondents, data processing using SPSS 22 using multiple linear regression analysis. The results showed that; The determining factor for employee performance in the Mamuju Regency trade office is organizational culture.
\end{abstract}

Keywords; Employee Competency, Organizational Culture, Performance

\begin{abstract}
Abstrak
Penelitian bertujuan untuk mengetahui dan menganalisis pengaruh kompetensi pegawai terhadap kinerja pegawai pada dinas perdagangan kabupaten Mamuju, menganalisis pengaruh budaya kerja terhadap kinerja pegawai dinas perdagangan kabupaten Mamuju. Pendekatan penelitian adalah kuantitatif deskriptif dengan jumlah sampel 40 responden, pengolahan data dengan menggunakan SPSS 22 dengan menggunakan analisis regresi linier berganda. Hasil penelitian menunjukkan bahwa;. Faktor penentu kinerja pegawai pada dinas perdagangan Kabupaten Mamuju adalah budaya organisasi.
\end{abstract}

Kata Kunci ; Kompetensi Pegawai, Budaya Organisasi, Kinerja 


\section{PENDAhUluAN}

Setiap organisasi dalam kegiatannya memerlukan aset pokok yang disebut sumber daya (resources), baik sumber daya alam (natural rosurces), maupun seumber daya manusia (human resources). Sumber daya manusia adalah asset yang paling penting dan membuat sumber daya organisasi lainnya bekerja. Sumber daya manusia sangat penting karena mempengaruhi efektivitas dan efisiensi organisasi, karena maju mundurnya suatu organisasi tergantung pada peran yang dijalankan oleh orang-orang yang ada di dalamnya.

Manusia selalu berperan aktif dan dominan dalam setiap kegiatan organisasi, karena manusia menjadi perencana, perilaku, dan penentu terwujudnya tujuan organisasi. Tujuan ini tidak mungkin terwujud tanpa adanya peran aktif dari mereka (Hasibuan, 2012).

Suatu organisasi dibentuk untuk mencapai tujuan bersama, namun untuk mencapai tujuan secara efektif diperlukan manajemen yang baik dan benar. Menurut Robbins dan Coultar dalam (Wibowo, Manajemen Kinerja, 2012), menyatakan bahwa manajemen sebagai suatu proses untuk membuat aktivitas terselesaikan secara efektif dan efisien dengan melalui orang lain. Efisiensi menunjukkan hubungan antara input dan output dengan mencari biaya sumber daya minimum, sedangkan efektif menunjukkan makna pencapaian tujuan yang telah ditetapkan sebelumnya.

Memahami kenyataan diatas, maka peranan Manajemen Sumber Daya Manusia dalam organisasi tidak hanya sekedar administrative tetapi justru lebih mengarah pada kemampuan untuk mengembangkan potensi sumber daya manusia agar menajdi kreatif dan inovatif. Sumber daya manusia merupakan ujung tombak yang akan menentukan keberhasilan pelaksanaan kegiatan perusahaan.

Menurut Amstrong dan Baron dalam (Wibowo, Manajemen Kinerja, 2012), menyatakan bahwa kinerja adalah merupakan hasil pekerjaan yang mempunyai hubungan yang kuat dengan tujuan strategis organisasi, kepuasan konsumen dan memberikan kontribusi ekonomi. Kinerja bukan hanya menyatakan sebagai hasil kerja, akan tetapi juga menyatakan tentang bagaimana proses kerja tersebut berlangsung.

Kompetensi adalah kemampuan kerja setiap individu yang mencakup aspek pengetahuan, keterampilan dan sikap kerja yang sesuai dengan standar yang ditetapkan. Kompetensi merupakan kombinasi dari keterampilan (skill), pengetahuan (knowledge), dan perilaku (attitude) yang diamati dan diterapkan secara kritis untuk suksesnya sebuah organisasi dan prestasi kerja serta kontribusi pribadi karyawan terhadap organisasinya (Watson Wyatt dalam Ruky, 2003:106).

Kinerja pegawai tidak selalu dalam kondisi yang baik. Kinerja dipengaruhi oleh beberapa faktor antara lain kemampuan dan keterampilan pegawai itu sendiri, ketersediaan fasilitas, motivasi dari pimpinan,system kompenasasi,volume pekerjaan yang diberikan, dan kerja sama rekan kerja (Hasibuan, 2011).

Pegawai yang memiliki kinerja yang tinggi akan memiliki tanggung jawab penuh terhadap pekerjaannya, berani mengambil resiko, memiliki tujuan yang realistis, memiliki rencana kerja dan berjuang untuk merealisasikan 
rencana tersebut. Manfaat penilaian kinerja bagi organisasi adalah meningkatkan keharmonisan hubungan dalam pencapaian tujuan organisasi, harapan jangka panjang dapat dikembangkan, budaya organisasi menjadi mapan, mendapatkan karyawan yang memiliki potensi menjadi pimpinan organisasi, dan keuntungan organisasi semakin meningkat.

Keberhasilan pegawai dalam melaksanakan tugasnya tergantung pada teknologi informasi,kompetensi SDM dan disiplin kerja. Suatu kenyataan yang dijumpai dalam organisasi karena kinerja seorang pegawai kadang-kadang belum dicurahkan sepenuhnya sesuai kecakapan dan kemampuan yang dimilikinya. Hal ini disebabkan oleh berbagai factor baik yang bersifat internal maupun yang bersifat eksternal. Salah satu factor yang menjadi penyebab utama rendahnya kinerja adalah pemberian imbalan gaji yang tidak seimbang, penempatan dalam job/pekerjaan yang kurang sesuai dengan kemampuan/keterampilan yang dimilikinya, kurangnya penghargaan atas prestasi yang dicapai,situasi lingkungan kerja yang kondusif, sarana dan prasarana kerja yang tidak memadai, kurangnya kesempatan mengikuti pendidikan dan latihan, promosi jenjang jabatan yang tidak jelas serta minimnya pemberian insentif.

Beberapa persoalan kinerja yang diamati penulis pada Dinas Perdagangan Kabupaten Mamuju antara lain adanya pegawai yang meninggalkan tempat kerja pada jam kerja tanpa alasan dan tujuan yang jelas, masih adanya pegawai yang hanya terlihat lebih sering duduk santai dan kurangnya kerjasama dalam melaksanakan tugas. Mencermati fenomena-fenomena tersebut, penulis tertarik untuk meneliti tingkat kinerja pegawai pada Dinas Perdagangan Kabupaten Mamuju dari aspek teknologi informasi, kompetensi sumber daya manusia (SDM) dan disiplin aparatur.

\section{TINJAUAN PUSTAKA}

\subsection{Penelitian terdahulu}

(Nurasiah Syarifuddin, Semmaila, \& Husain, 2019) Tujuan penelitian ini adalah untuk menganalisis pengaruh Gaya Kepemimpinan, Motivasi Kerja Dan Kompetensi Terhadap Kinerja Pegawai Pada Kantor Badan Pengelolaan Keuangan Kabupaten Gowa. Jumlah pegawai pada Kantor Badan Pengelolaan Keuangan Kabupaten Gowa adalah 65 orang. Sampel dalam penelitian ini adalah keseluruhan jumlah populasi yaitu 65 responden. Teknik analisis yang digunakan dalam penelitian ini adalah analisis deskriptif dan analisis regresi linear berganda.

Pengumpulan data dilakukan dengan menyebarkan kuesioner kepada pegawai yang dijadikan sampel dalam penelitian ini. Hasil penelitian ini menunjukkan bahwa secara parsial variabel gaya Kepemimpinan, motivasi kerja dan kompetensi terhadap kinerja pegawai pada kantor Badan Pengelolaan Keuangan Kabupaten Gowa. Secara simultan variabel gaya Kepemimpinan, motivasi kerja dan kompetensi terhadap kinerja pegawai pada kantor Badan Pengelolaan Keuangan Kabupaten Gowa. Sedangkan variabel motivasi kerja merupakan variabel paling dominan mempengaruhi kinerja pegawai pada kantor Badan Pengelolaan Keuangan Kabupaten Gowa.

(Amri Rizqina, Adam, \& Chan, 2017) Bagian organisasi yang menjadi faktor penentu untuk tercapainya tujuan yang diharapkan adalah sumber daya manusia, dimana sumber daya manusia 
diharapkan bisa menjadi bagian dari organisasi yang dapat meningkatkan dan menciptakan nilai kompetitif organisasi. Badan Pengusahaan Kawasan Perdagangan Bebas dan Pelabuhan Bebas Sabang (BPKS) secara nyata dan bersinergi, pegawai selaku pekerja yang melaksanakan tugas dan fungsi tersebut harus memiliki tanggung jawab dan kemampuan bekerja yang baik dan terstruktur sehingga dapat mencapai tujuan perusahaan.

Populasi dalam penelitian ini adalah pegawai Badan Pengusahaan Kawasan Perdagangan Bebas dan Pelabuhan Bebas Sabang (BPKS) Pusat yaitu sebanyak 135 orang dan pengambilan sampel dilakukan dengan teknik sensus. Pembuktian Hipotesis dilakukan dengan menggunakan indikator nilai CR dan P. Karena dari 8 hipotesis verifikatif yang diuji dalam penelitian ini memilik nilai CR diatas 1,96 atau nilai $P$ lebih kecil dari 0,05, maka semua hipotesis yang diuji menolak Ho dan menerima H1. Dengan kata lain variable independen dan intervening memiliki pengaruh untuk meningkatkan variabel dependent sepanjang variabel independent dan intervening dapat ditingkatkan oleh pengelola kantor BPKS Sabang.

\subsection{Pengertian Kompetensi}

Menurut Amstrong dan Baron dalam (Wibowo, Manajemen Kinerja, 2012) kompetensi merupakan dimensi perilaku yang berada di belakang kinerja kompeten. Sering dinamakan kompetensi perilaku karena dimaksudkan untuk menjelaskan bagaimana orang berperilaku ketika mereka menjalankan perannya dengan baik.

McAshan dalam (Sudarmanto, 2009) kompetensi merupakan pengetahuan, keahlian dan kemampuan yang dimiliki seseorang, yang menjadi bagian dari dirinya, sehingga dia bisa menjalankan penampilan kognisi,afeksi dan perilaku psikomotorik tertentu.

Pengertian dan arti kompetensi menurut Lyle Spencer \& Signe Spencer dalam (Moeheriono, 2010) adalah karakteristik yang mendasari seseorang berkaitan dengan efektivitas kinerja individu dalam pekerjaannya atau karakteristik dasar individu yang memiliki hubungan kausal atau sebagai sebab akibat dengan kriteria yang dijadikan acuan, efektif atau berkinerja prima atau superior di tempat kerja atau pada situasi tertentu.

Spencer dalam (Wibowo, Manajemen Kinerja, 2012) juga mengatakan bahwa kompetensi merupakan landasan dasar karakteristik orang dan mengindikasikan cara berperilaku atau berpikir, menyamakan situasi, dan mendukung untuk periode waktu yang cukup lama.

Kompetensi merupakan landasan dasar karaketristik orang dan mengindikasikan cara berperilaku atau berpikir, menyamakan situasi dan mendukung untuk periode waktu cukup lama (Spancer, 2011).

Menurut (Marwansyah, 2016) kompetensi adalah perpanduan pengetahuan, keterampilan, sikap dan karakteristik pribadi lainnya yang diperlukan untuk mencapai keberhasilan dalam sebuah pekerjaan, yang bisa diukur dengan menggunakan standar yang telah disepakati, dan yang dapat ditingkatkan melalui pelatihan dan pengembangan.

Dari berbagai pandangan diatas, dapat disimpulkan bahwa kompetensi merupakan kemampuan menjalankan tugas atau pekerjaan dengan dilandasi oleh pengetahuan, keterampilan dan di 
dukung oleh sikap yang menjadi karakteristik individu.

\subsection{Faktor-Faktor Yang Mempengaruhi Kompetensi}
Michael
Zwell
(dalam

Wibowo,2016) mengungkapkan bahwa terdapat beberapa 8 faktor yang dapat mempengaruhi kecakapan kompetensi seseorang, yaitu sebagai berikut : a) Keyakinan dan Nilai-nilai, b) keterampilan, c) pengalaman, d) karekteristik kepribadian, e) motivasi, f) isu emosional, g) kemampuan intelektual, dan h) budaya organisasi

\section{a. Budaya Kerja}

Di setiap organisasi pastinya ada budaya kerja yang menjadi ciri khas organisasi tersebut. Budaya kerja yang positif ini penting ntuk dijalankan dalam sebuah organisasi agar kinerjanya produktif. Menurut Taliziduhu Ndraha (2003:81) dalam (Amantha, 2016), budaya kerja dapat dibagi menjadi dua unsur, yaitu:

1) Sikap terhadap pekerjaan, yakni kesukaan akan kerja dibandingkan dengan kegiatan lain, seperti bersantai, atau semata-mata memperoleh kepuasan dari kesibukan pekerjaannya sendiri, atau merasa terpaksa melakukan sesuatu hanya untuk kelangsungan hidupnya.

2) Perilaku pada waktu bekerja, seperti rajin, berdedikasi, bertanggung jawab, berhati-hati, teliti, cermat, kemauan yang kuat untuk mempelajari tugas dan kewajibannya, suka membantu sesama pegawai, atau sebaliknya.

Gering,Supriyadi dan Triguno 2001 dalam (Maharani, 2013) budaya kerja adalah suatu falsafah dengan didasari pandangan hidup sebagai nilai-nilai yang menjadi sifat, kebiasaan dan juga pendorong yang dibudayakan dalam suatu kelompok dan tercermin dalm sikap menjadi perilaku,cita-cita,pendapat pandangan serta tindakan yang terwujud sebagai kerja atau bekerja.

Budaya kerja adalah cara pandang seseorang dalam memberi makna terhadap kerja. Dengan demikian, budaya kerja merupaka cara pandang seseorang terhadap bidang yang ditekuninya dan prinsip-prinsip moral yang dimiliki, yang menumbuhkan keyakinan yang kuat atas dasar nilai-nilai yang diyakini, memiliki semangat yang tinggi dan bersungguh-bersungguh untuk mewujudkan prestasi terbaik.

Dapat disimpulkan bahwa budaya kerja adalah perilikau atau tindakan setiap individu dalam satu organisasi yang mana tindakan tersebut sudah menjadi kebiasaan.

\section{b. Dimensi Budaya Kerja}

Harrison dan Stokes 1992 dalam (Mohammad, 2015) jurnal dampak budaya kerja terhadap kinerja karyawan, membedakan budaya organisasi menjadi 4 (empat) dimensi yang merupakan orientasi budaya yang dipersepsikan oleh para anggotanya yaitu :

1) The Power Orientation (Orientasi pada Kekuasaan)

Perusahaan yang berorientasi pada kekuasaan didasarkan atas perbedaan akses kepada sumber. Orang-orang yang berkuasa menggunakan sumber-sumber untuk mengendalikan perilaku orang lain. Para anggota organisasi ditimbulkan motivasinya oleh imbalan dan hukuman, dan oleh keinginan untuk bekerja dengan pimpinan yang kuat. Di dalam perusahaan yang berorientasi pada kekuasaan, kepemimpinan berdasar atas kekuatan, keadilan dan kebajikan. Pemimpinnya merasa bertanggungjwab kepada bawahannya. Orientasi kekusasaan sagat sesuai dengan situasi 
saat pemimpi mempunyai visi,intelejensi, dan berkeinginan utuk mengelolah usaha dan mengawasi langsung aktivitas bawahannya. Ada hubungan yag sifatnya personal antara pemimpin dan pengikutnya, serta terdapat ketergantungan pegikut atau bawahan terhadap petunjuk dan keamanan dari pemimpin. Ketergantungan pada pemimpin disini sangatlah tinggi.

Kejelekkan dari tipe ini yaitu tunduk pada peraturan karena takut, dan terdapat penyalahgunaan kekuasaa bagi pihak-pihak yang ada disekitar pemimpin. Jika usaha semakin kompleks da bertambah besar, orientasi pada kekusaan tidak akan efisien dan menjadi berantakan jika tidak dilengkapi oleh struktur dan sistem yang baik untuk menyelesaikan pekerjaan. Karena jarak antara pemimpin dan pengikut semakin lebar, menyelesaikan yang efektif menjadi semakin sulit.

2) The Role Orientation (Orientasi pada Peran)

Orientasi pada peran menempatkan sebuah sistem dari struktur dan prosedur untuk menggantikan kekuasaan pemimpin. Struktur dan sistem memberikan proteksi terhadap peraturan hukum. Kewajiban imbalan bagi anggota atau bawahan didefinisikan dengan teliti, biasanya secara tertulis dan mengadakan kontrak yang eksplisit atau implisit antara organisasi dan individu. Orang menjalankan fungsi khusus untuk menerima imbalan yang ditetapkan. Nilai dari orientasi peran yaitu yang berkaitan dengan nilai-nilai yang mengutamakan pada keterkaitan, rasionalitas dan konsistensi.

Sistem dalam organisasi tersebut kinerjanya diorganisasi oleh struktur dan prosedur, bukan diawasi secara pribadi oleh pemimpin. Wewenang dan tanggung jawab didelegasikan kebawah. Masingmasing tingkatan didalam organisasi memiliki bidang wewenang yang ditetapkan, tanpa ada pengawasan langsung dari atas.

Keunggulannya, organisasi yang berorientasi pada peran memberikan stabilitas, keadilan dan kenerja yang efisien. Kelemahannya adalah mereka bekerja pada asumsi bahwa orang tidak bisa dipercaya, sehingga mereka tidak memberikan otonomi secara invidu kepada anggota pada tingkat yang lebih rendah. Sistem dirancang untuk mengawasi orang-orang dan mencegah mereka untuk melaksanakan tindakan yang mementingkan dirinya sendiri.

3) The Achievement Orientation (Operasi pada Prestasi)

Organisasi yang berorientasi pada prestasi disebut juga organisasi sejajar, karena tipe ini menggunakan misi untuk menarik dan mengeluarkan energi perorangan dari pada anggotanya untuk mengejar tujuan bersama. Pada anggota memberikan kontribusi mereka dengan bebas sebagai respon terhadap komitmen mereka kepada tujuan yang dibagi, mereka dengan sukarela memberi lebih banyak kepada organisasi. Organisasi ini menekankan pada motivasi yang tinggi daripada anggota organisasi untuk menghilangkan ketidakefisienan dari struktur, sistem, dan perencanaan, dalam budaya ini tujuan utama organisasi adalah mendorong para anggota untuk mencapai tujuan bersama.

Organisasi yang berorientasi kepada prestasi sering kali kurang terorganisir, ia berpegang pada motivasi tinggi untuk mengatasi kekurangannya didalam struktur, system dan perencanaan. Apalagi jika para 
anggotanya mengalami kebosanan, organisasi/perusahaan bisa kehilangan fokus dan kesatuan usaha jika tugasnya kompleks dan visi yang berbeda untuk masing-masing bagian yang berbeda dalam perusahaan karena tidak berdasar sistem dan prosedur.

\section{4) The Support Orientation (Orientasi pada Dukungan)}

Iklim dalam organisasi yang didasarka pada saling percaya ddiantara para anggota sebagai individu dengan organisasi itu sendiri. Dalam kondisi pegawai yakin bahwa mereka dinilai sebagai manusia, bukan hanya sebagai mesin. Ada kehangatan yang mendorong semangat dalam organisasi. Orang berangkat pada pagi hari ketempat kerja bukan hanya karena menyukai pekerjannya saja, tetapi juga kerena mereka peduli kepada lingkugan sekelilingnya.

Organisasi yang berorenintasi pada dukungan menawarkan kepada anggotanya kepuasan yang bersal dari hubungan. Dengan asumsi orang-orang akan memmberikan kontribusi karena komitmen kepada suatu kelompok atau organisasi karena mereka memiliki rasa memiliki. Ada keinginan para anggota kelompok untuk berkorban demi anggota kelompok lainnya.

Kelemahan tipe ini adalah cenderung menghindari konflik untuk keselarasan organisasi. Konsensus ini mungkin dinilai berlebihan karena menghambat kemampuan organisasi untuk bergerak dengan tegas.

Setiap organisasi memiliki gabungan dari keempat macam budaya tersebut. Masing-masing menyebabkan perbedaan perilaku dan didasarkan atas berbagai nilai kemanusiaan. Masingmasing mencakup cara yang unik untuk membuat keputusan, cara untuk memotivasi orang agar bekerja, gaya manajemen yang khas, dan seperangkat nilai dan kepercayaan yang mendasari mengenai pekerjaan dan sifat manusia.

\subsection{Kinerja}

(Sapitri, 2016) mengutip Christie Dkk (2010) yang menyatakan bahwa kinerja adalah pencapaian suatu hasil yang dikarakteristikkan dengan keahlian tugas seseorang ataupun kelompok atas dasar tujuan yang telah ditetapkan. Bernandin, John H \& Joyce E.A Russel (1993) kinerja dinyatakan sebagai catatan outcomes yang dihasilkan dari suatu aktifits tertentu, selama kurun waktu tertentu. Penilaian kinerja individu sangat bermanfaat bagi pertumbuhan perusahaan secara kesulurahan, melalui penilaian tersebut maka dapat diketahui kondisis sebenarnya tentang bagaimana kinerja karyawan.

(Jailani, 2017) mengutip Stephen P. Robbin (1997: 26) yang mengatakan bahwa kinerja adalah suatu ukuran performance yang meliputi efektivitas dan effisiensi. Efektif berkaitan dengan pencapaian sasaran,sedang efisien adalah ratio antara output yang efektif dengan input yang diperlukan untuk mencapai sasaran.

Menurut (Hasibuan, 2012) kinerja pegawai merupakan suatu hasil kerja yang dicapai seseorang dalam melaksanakan tugas-tugas yang diberikan kepadanya berdasarkan atas kecakapan pengalaman dan kesungguhan serta waktu. Kemudian Arif Yusuf Hambali (2016) menambahkan bahwa kinerja merupakan hasil pekerjaan yang mempunyai hubungan kuat dengan tujuan strategi organisasi, keputusan konsumen, dan memberikan kontribusi pada ekonomi. Sedangkan Wirawan 
dalam (Hamid, 2015) mengatakan kinerja adalah keluaran yang dihasilkan oleh fungsi-fungsi atau indikatorindikator suatu pekerjaan atau suatu profesi dalam waktu tertentu.Definisi kinerja juga ditambahkan oleh (Bangun, 2012) bahwa kinerja adalah hasil pekerjaan yang dicapai seseorang berdasarkan persyaratan-persyaratan pekerjaan.

Menurut (Hasibuan, 2012) indikator atau ukuran yang dapat digunakan dalam penilaian kinerja adalah sebagai berikut: Kecakapan / kemampuan; Prestasi Kerja; Kejujuran; Kedisiplinan; Kreativitas; Kerjasama; Kepemimpinan; Kepribadian; Prakarsa; Kesetiaan; dan Tanggungjawab.

Untuk mendapatkan informasi mengenai kualitas dan kuantitas kerja seorang karyawan, maka perlunya perusahaan tersebut melakukan penilaian terhadap kinerja karyawannya/pegawainya.

\subsection{Indikator Kinerja Pegawai}

Dalam Peraturan Pemerintah (PP) Nomor 30 Tahun 2019 tentang Penilaian Kinerja Pegawai Negeri Sipil (PNS), Penilaian Kinerja PNS bertujuan untuk menjamin objektivitas pembinaan PNS yang didasarkan pada sistem prestasi dan sistem karier. Penilaian dilakukan berdasarkan perencanaan kinerja pada tingkat individu dan tingkat unit atau organisasi, dengan memperhatikan target, capaian, hasil, dan manfaat yang dicapai, serta perilaku PNS.

Pasal 4 Peraturan Pemerintah (PP) Nomor 30 Tahun 2019 tentang Penilaian Kinerja Pegawai Negeri Sipil (PNS) berbunyi "Penilaian Kinerja PNS dilakukan berdasarkan prinsip a. objektif; b. terukur; c. akuntabel; d. partisipatif; dan e. transparan".
Penilaian Kinerja PNS sebagaimana dimaksud Peraturan Pemerintah (PP) Nomor 30 Tahun 2019 tentang Penilaian Kinerja Pegawai Negeri Sipil (PNS), dilaksanakan dalam suatu Sistem Manajemen Kinerja PNS yang terdiri atas: a. perencanaan kinerja; b. pelaksanaan, pemantauan kinerja, dan pembinaan kinerja; c. penilaian kinerja; d. tindak lanjut; dan e. Sistem Informasi Kinerja PNS.

Dalam Peraturan Pemerintah (PP) Nomor 30 Tahun 2019 tentang Penilaian Kinerja Pegawai Negeri Sipil (PNS)Perencanaan Kinerja terdiri atas penyusunan dan penetapan SKP (Sasaran Kinerja Pegawai) dengan memperhatikan Perilaku Kerja.

Proses penyusunan SKP yang dimaksud dalam Peraturan Pemerintah (PP) Nomor 30 Tahun 2019 tentang Penilaian Kinerja Pegawai Negeri Sipil (PNS), dilakukan dengan memperhatikan: a. perencanaan strategis Instansi Pemerintah; b. perjanjian kinerja; c. organisasi dan tata kerja; d. uraian jabatan; dan/atau e. SKP atasan langsung.

"SKP sebagaimana dimaksud memuat kinerja utama yang harus dicapai seorang PNS setiap tahun.Selain kinerja utama sebagaimana dimaksud, SKP dapat memuat kinerja tambahan," demikian bunyi Pasal 9 ayat (1 dan 2) Peraturan Pemerintah (PP) Nomor 30 Tahun 2019 tentang Penilaian Kinerja Pegawai Negeri Sipil (PNS). SKP bagi pejabat pimpinan tinggi, menurut Peraturan Pemerintah (PP) Nomor 30 Tahun 2019 tentang Penilaian Kinerja Pegawai Negeri Sipil (PNS) ini, disusun berdasarkan perjanjian kinerja Unit Kerja yang dipimpinnya dengan memperhatikan: a. rencana strategis; dan b. rencana kerja tahunan. 
SKP bagi pejabat pimpinan tinggi utama, menurut Peraturan Pemerintah (PP) Nomor 30 Tahun 2019 tentang Penilaian Kinerja Pegawai Negeri Sipil (PNS), disetujui oleh menteri yang mengoordinasikan. SKP bagi pejabat pimpinan tinggi madya disetujui oleh pimpinan Instansi Pemerintah. Sedangkan SKP bagi pejabat pimpinan tinggi pratama disetujui oleh pejabat pimpinan tinggi madya.

Penilaian kinerja PNS sebagaimana dimaksud dapat dilakukan dengan memberikan bobot masing-masing unsur penilaian: a.70\% (tujuh puluh persen) untuk penilaian SKP, dan 30\% (tiga puluh persen) untuk penilaian Perilaku Kerja; atau b.60\% (enam puluh persen) untuk penilaian SKP, dan 40\% (empat puluh persen) untuk penilaian Perilaku Kerja.

Penilaian Kinerja PNS dengan bobot $70 \%$ (tujuh puluh persen) untuk penilaian SKP dan 30\% (tiga puluh persen) untuk penilaian Perilaku Kerja sebagaimana dimaksud, menurut PP ini, dilakukan oleh Instansi Pemerintah yang tidak menerapkan penilaian Perilaku Kerja dengan mempertimbangkan pendapat rekan kerja setingkat dan bawahan langsung.

Sedangkan Penilaian Kinerja PNS dengan bobot $60 \%$ (enam puluh persen) untuk penilaian SKP dan 40\% (empat puluh persen) untuk penilaian Perilaku Kerja, menurut PP ini,dilakukan oleh Instansi Pemerintah yang menerapkan penilaian Perilaku Kerja dengan mempertimbangkan pendapat rekan kerja setingkat dan bawahan langsung.

Menurut Peraturan Pemerintah (PP) Nomor 30 Tahun 2019 tentang Penilaian Kinerja Pegawai Negeri Sipil (PNS) ini, penilaian Kinerja PNS dinyatakan dengan angka dan sebutan atau predikat sebagai berikut:

a. Sangat Baik, apabila PNS memiliki: 1) nilai dengan angka 110 (seratus sepuluh) - 120 (seratus dua puluh); dan 2) menciptakan ide baru dan/atau cara baru dalam peningkatan kinerja yang memberi manfaat bagi organisasi atau negara;

b. Baik, apabila PNS memiliki nilai dengan angka 90 (sembilan puluh) angka 120 (seratus dua puluh); c. Cukup, apabila PNS memiliki nilai dengan angka 70 (tujuh puluh) <angka 90 (sembilan puluh);

c. Kurang, apabila PNS memiliki nilai dengan angka 50 (lima puluh) - angka 70 (tujuh puluh); dan

d. Sangat Kurang, apabila PNS memiliki nilai dengan angka $<50$ (lima puluh).

Peraturan Pemerintah (PP) Nomor 30 Tahun 2019 tentang Penilaian Kinerja Pegawai Negeri Sipil (PNS) juga menyebutkan, distribusi PNS yang mendapatkan predikat penilaian kinerja sebagaimana dimaksud dengan ketentuan: a) paling tinggi 20\% (dua puluh persen) dari total populasi pegawai dalam satu unit kerja berada pada klasifikasi status kinerja "di atas ekspektasi"; b) paling rendah 60\% (enam puluh persen) dan paling tinggi $70 \%$ (tujuh puluh persen) dari total populasi pegawai dalam satu unit kerja berada pada klasifikasi status kinerja "sesuai ekspektasi"; dan c) paling tinggi 20\% (dua puluh persen) dari total populasi pegawai dalam satu unit kerja PNS berada pada klasifikasi status kinerja "di bawah ekspektasi”.

Kinerja PNS adalah hasil kerja yang dicapai oleh setiap PNS pada organisasi/unit sesuai dengan SKP dan perilaku kerja. Menurut Akdon dalam (www.perpuskampus.com, 
terdapat 5 (lima) macam indikator kinerja yang umumnya digunakan yakni: (a) indikator kinerja input (masukan) adalah indikator segala sesuatu yang dibutuhkan agar pelaksanaan kegiatan dapat menghasilkan keluaran yang ditentukan; misal dana, SDM, informasi, kebijakan dan lain-lain, (b) Indikator Process: gambaran mengenai langkahlangkah yang dilaksanakan dalam menghasilkan barang atau jasa (frekuensi proses, ketaatan terhadap jadwal, dan ketaatan terhadap ketentuan/standar). (c) indikator kinerja output (keluaran) adalah sesuatu yang mencerminkan berfungsinya keluaran (output) kegiatan pada jangka menengah (efek langsung), (d) indikator kinerja benefit (manfaat) adalah sesuatu yang terkait dengan tujuan akhir dari pelaksanaan kegiatan, (e) indikator kinerja impact (dampak ) adalah pengaruh yang ditimbulkan baik positif maupun negatif pada setiap tingkatan indikator berdasarkan asumsi yang telah ditetapkan. Sementara indikator kinerja menurut Anwar Prabu Mangkunegara dalam (www.perpuskampus.com, 2016) yaitu: a) kualitas; b) kuantitas ; c) pelaksanaan tugas; d) tanggung jawab

\subsection{Kerangka Konseptual}

Sejalan dengan berbagai kajian teori dan referensi seperti yang disebutkan sebelumnya, maka penelitian akan memiliki kerangka konseptual atau jalur analisis sebagai berikut :

Selanjutnya untuk meningkatkan kinerja dalam melaksanakan kegiatan sehari-hari perlu diubah cara bekerjasama dari bagaimana melihat atau meninjau kinerja itu sendiri. Dengan demikian pimpinan dan pegawai yang bertanggung jawab langsung dalam pelaksanaan kinerja harus pula dievaluasi secara periodik. Dalam kenyataannya terdapat 2 (dua) faktor yang mempengaruhi pencapaian kinerja adalah faktor kemampuan dan faktor motivasi (motivation).(Nenny Anggraeni, 2012).

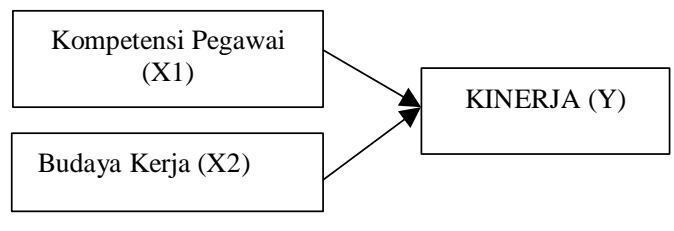

Gambar 1. Kerangka Konseptual

Penilaian kinerja individu sangat bermanfaat bagi dinamika pertumbuhan organisasi secara keseluruhan, melalui penilaian tersebut maka dapat diketahui kondisi sebenarnya tentang bagaimana kinerja pegawai. Ada enam kinerja primer yang dapat digunakan untuk mengukur kinerja yaitu 1) Kualitas pekerjaan (quality), 2) Kuantitas (quantity), 3) Ketepatan waktu (timeliness), 4) Efektifitas biaya (cost efectiveness), 5) Kemandirian. (Nurasiah Syarifuddin, Semmaila, \& Husain, 2019)

H1 : Variabel Kompetensi memberi pengaruh positif dan signifikan terhadap kinerja pegawai pada dinas perdagangan kabupaten Mamuju.

Kompetensi sumber daya manusia adalah karakeristik yang menasari seseorang berkaitan dengan efektivitas kinerja individu dalam pekerjaannya : a) pengetahuan, b) keterampilan dan c) sikap kerja.

H2 : Variabel budaya kerja memberi pengaruh positif dan signifikan terhadap kinerja pegawai pada dinas perdagangan kabupaten Mamuju

Budaya kerja adalah perilaku individu yang dilakukan berulang-ulang oleh dalam suatu organisasi dan telah menjadi kebiasaan dalam melaksanakan suatu pekerjaan. Budaya kerja merupakan falsafah sebagai nilai-nilai yang menjadi sifat, kebiasaan, dan kekuatan pendorong yang dimiliki 
bersama oleh setiap individu dalam lingkungan kerja suatu organisasi.

\section{METODE PENELITIAN}

Metode penelitian kuantitatif dapat diartikan sebagai metode penelitian yang berlandaskan pada filsafat positivism, digunakan untuk meneliti pada populasi atau sampel tertentu, pengumpulan data menggunakan instrument penelitian, analisis data bersifat kuantitatif/statistic, dengan tujuan menguji hipotesis yang ditetapkan (Sugiyono, 2017).

Populasi adalah keseluruhan subjek penelitian (Arikunto, 2013). Populasi adalah seluruh data yang menjadi perhatian kita dalam suatu ruang waktu yang kita tentukan(Syafi'i, 2005). Selanjutnya populasi menurut Joko Subagyo adalah objek penelitian sebagai sasaran untuk mendapatkan dan mengumpulkan data (Syafi'i A, 2005). Adapun populasi dalam penelitian ini adalah seluruh pegawai Kantor Dinas perdagangan Kabupaten Mamuju sebanyak 40 orang.

Jumlah pegawai yang menjadi populasi di kantor Dinas Perdagangan kabupatan Mamuju sebanyak 40 orang. Pengambilan sample ini berdasarkan sampel jenuh. Dimana semua populasi dari penelitian dijadikan sebagai sampel (Sugiyono, 2017). Teknik Pengumpulan Data adalah dengan menyebar angket/kuisioener.

Analisis data yang berhasil dikumpulkan akan diolah menggunakan alat SPSS, dengan pengujian deskriptif, uji validitas, uji reliabilitas, uji normalitas, heterokedastisitas, multikolinearitas, uji autokorelasi DW, uji inferensial.

\section{HASIL DAN PEMBAHASAN}

Tabel 1. Hasil Pengujian Hipotesis Secara Parsial (Uji t)

\begin{tabular}{|c|c|c|c|c|c|c|}
\hline \multirow[b]{2}{*}{ Had? } & & \multicolumn{2}{|c|}{ Unstentardesd Coefficents } & \multirow{2}{*}{$\begin{array}{c}\begin{array}{l}\text { Standades } \\
\text { Cosfivients }\end{array} \\
\text { Bdia } \\
\end{array}$} & \multirow[b]{2}{*}{$t$} & \multirow[b]{2}{*}{$5 g$} \\
\hline & & $B$ & Stid Emrr & & & \\
\hline 1 & (Constare) & -13274 & 7,718 & & -1722 & 184 \\
\hline & $x$ & 796 & 310 & 331 & 254 & $\$ 16$ \\
\hline & 12 & .476 & .141 & 497 & 3.377 & .002 \\
\hline
\end{tabular}

3. Derendart Variatla: Y

Berdasarkan tabel 1, hasil pengujian terhadap variabel kompetensi (X1) menunjukkan bahwa nilai nilai thitung 2,541 > t-tabel 1,999 dan tingkat signifikan sebesar 0,016. Hasil penelitian menunjukkan bahwa variabel kompetensi (X1)tidak berpengaruh secara positif dan signifikan terhadap kinerja pegawai. Dengan demikian hipotesis yang diajukan dapat ditolak.

Hasil pengujian terhadap variabel budaya kerja (X2) menunjukkan bahwa nilai nilai t-hitung 3,377 > t-tabel 1,999 dan tingkat signifikan sebesar 0,002. Hasil penelitian menunjukkan bahwa variabel motivasi kerja (X2) berpengaruh secara positif dan signifikan terhadap kinerja pegawai. Dengan demikian hipotesis yang diajukan dapat diterima.

\subsection{Pengaruh kompetensi sumber daya manusia terhadap kinerja pegawai pada dinas Perdagangan kabupaten Mamuju.}

Berdasarkan hasil tabel frekuensi variable deskripsi kompetensi sumber daya manusia memberikan informasi bahwa total responden yang memberikan jawaban $\mathrm{N}=40$, dengan respon setuju dan sangat setuju $(63,75 \%+24,58 \%)=89 \%$ dan sisanya sebesar $11 \%$ menjawab raguragu(netral), sedangkan nilai rata-rata 
(mean) yang diperoleh sebesar 4,13 dengan nilai rentang masuk pada kreteria "baik".

Berdasarkan keterangan di atas, bahwa pegawai di kantor dinas perdagangan kota Mamuju sangat menyadari pentingnya kompetensi sumber daya manusia sehingga oleh kebijakan pimpinan memberikan peluang dan kesempatan kepada setiap pegawai untuk mengikuti pelatihan dan pendidikan dalam rangka peningkatan kompetensi tersebut. Selain itu, kompetensi dipandang sangat dibutuhkan oleh Aparat Sipil Negara (ASN) hal tersebut selain melaksanakan tugas pokok sebagai abdi Negara juga melaksanakan pelayanan ke public (masyarakat) yang perlu diberikan pelayanan yang maksimal (exelent), hal tersebut harus didukung oleh kompetensi sumber daya manusia terutama pengetahuan, keterampilan dan sikap.

Hasil penelitian menunjukkan bahwa variabel kompetensi tidak berpengaruh terhadap kinerja pegawai pada dinas perdagangan kabupaten Mamuju. Artinya bahwa kompetensi bukan menjadi jaminan pegawai tersebut memiliki kinerja yang baik. Bisa saja ada motivasi yang menyebabkan kinerja pegawai baik.

Sementara pada hasil penelitian emperik oleh (Jufri, 2018) yang membahas tentang Kompetensi Sumber Daya Manusia di Kantor Samsat Wilayah Gowa, dengan hasil penelitian menyebutkan bahwa pegawai telah memiliki karakteristik kompetensi yang sudah sangat bagus, pengetahuan yang didukung oleh pendidikan dan pengalaman sudah sesuai dengan disiplin ilmu pegawai dengan pekerjaan yang diberikan kepada pegawai, keterampilan berkomunikasi dan mengoperasikan teknologi informasi juga bagus, serta sikap pegawai menunjukkan sikap disiplin dan tanggung jawab terhadap pekerjaan juga sangat bagus.

Pengalaman, kreativitas, dan motivasi merupakan faktor yang sangat mempengaruhi meningkatnya kompetensi sumber daya manusia di kantor Samsat wilayah Gowa dan hasil pengujian hipotesisnya memberikan hasil bahwa kompetensi sumber daya manusia memberikan pengaruh positif dan signifikan terhadap kinerja pegawai.

\subsection{Pengaruh Budaya Kerja terhadap kinerja pegawai pada dinas Perdagangan kabupaten Mamuju. \\ Dari pengujian deskriptif terhadap} budaya kerja dari responden sebanyak 40 orang pegawai, memberikan hasil bahwa dari respon dengan tingkat frekuensi paling tinggi adalah respon sangat setuju (5) dan respon yang paling rendah (minimum) dengan nilai 4 (setuju), dengan jumlah perolehan ratarata sebanyak 170 (dibulatkan) dengan nilai mean 4,25 dengan sebutan kategori dengan hasil"baik".

Hasil penelitian emperik yang diperoleh dari pengolahan data SPSS melalui pengujian hipotesis menggunakan uji $t$ (parsial) memberikan hasil bahwa, perhitungan (model) sig.<alpha 0,05, dan hal ini dapat ditarik kesimpulan bahwa hipotesis budaya kerja berpengaruh positif signifikan terhadap kinerja pegawai diterima $(\mathrm{H} 2)$ dan hipotesis nully (HO) ditolak. Hasil penelitian emperik lainnya yang membahas tentang pengaruh variable budaya kerja terhadap kinerja pegawai yaitu penelitian ini mendukung hasil penelitian (Amri Rizqina, Adam, \& Chan, 
2017) yang menyatakan bahwa, budaya kerja berpengaruh signifikan terhadap kinerja pegawai pada Badan Pengusahaan Kawasan Perdagangan Bebas Dan Pelabuhan Bebas Sabang (BPKS).

\section{PENUTUP}

\subsection{Simpulan}

1. Bahwa hipotesis variabel kompetensi pegawai berpengaruh positif dan signifikan terhadap variabel kinerja pegawai, dapat dibuktikan dengan hasil t- hitung X2 (Kompetensi Pegawai) dengan probabilitas (Sig) 0,016>dari alpha $(\alpha)$ 0,05 berarti pengaruh X2 tidak signifikan, hasil tersebut menjelaskan bahwa $\mathrm{H} 2$ ditolak dan Ho diterima (kompetensi pegawai tidak berpengaruh signifikan terhadap kinerja pegawai).

2. Bahwa hipotesis variabel budaya kerja berpengaruh positif dan signifikan dibuktikan dengan t-hitung X3 (budaya kerja) dengan probabilitas (Sig) $0,02<$ alpha $(\alpha)$ 0,05, hal ini menjelaskan bahwa hipotesis yang diajukan diterima (H3) dan Ho ditolak.

\subsection{Saran}

1. Untuk mendukung upaya-upaya peningkatan kompetensi sumber daya manusia maka pegawai perlu dibekali dengan kursus-kursus pelatihan yang berhubungan dengan pekerjaannya terutama pada peningkatan kapasitas pengetahuan keterampilan teknologi dan informasi agar dalam pelaksanaan tugas keseharian dapat diselesaikan dengan cepat dan tepat. Memberikan kesempatan kepada pegawai yang ingin meningkatkan diri melalui tugas belajar dan memberi reward kepada pegawai yang kinerjanya baik sehingga menjadi motivasi untuk terus bekerja lebih baik.

2. Budaya kerja dalam suatu organisasi haruslah dipahami oleh semua pegawai dan dilaksanakan dengan baik agar tujuan organisasi dapat tercapai. Sehingga budaya organisasi haruslah diperhatikan oleh pemilik ataupun pemimpin organisasi untuk terus memberikan motivasi kepada bawahan yang kurang taat terhadap budaya organisasi yang selama ini telah disepakati. Pemberian sanksi kepada pegawai terhadap pelanggaran budaya organisasi juga di perlukan untuk menciptakan budaya organisasi yang lebih baik.

3. Bagi peneliti lain,yang akan meneliti hal-hal yang berhubungan dengan kinerja dapat menambah variabel bebas lain atau faktor-faktor yang lain yang dapat meningkatkan kinerja organisasi.

\section{DAFTAR PUSTAKA}

Amantha, G. K. (2016). Tesis :Analisis Budaya Kerja Dalam Menciptakan Sumber Daya Manusia Yang Berkualitas (Studi Pada Biro Organisasi Sekretariat Daerah Provinsi Lampung). Bandar Lampung: Universitas Lampung.

Amri Rizqina, Z., Adam, M., \& Chan, S. (2017, September). Pengaruh Budaya Kerja, Kemampuan dan Komitmen Kerja Terhadap Kepuasan Kerja Pegawai Serta Dampaknya Terhadap Kinerja Badan Pengusahaan Kawasan Perdagangan Bebas dan Pelabuhan Bebas Sabang (BPKS). Jurnal Magister Manajemen, I(1), 59-69.

Arikunto. (2013). Prosedur Penelitian: Suatu Pendekatan Praktik. Jakarta: Rineka Cipta. 
Azmi, Y. (2015, 11 3). yanazami. Retrieved Februari 25, 2020, from http://yanazami.blogspot.com/2 015/11/pengertian-informasihtml

Bangun, W. (2012). Manajemen Sumber Daya Manusia. Penerbit Erlangga.

Dr.Rasto, M. (2016, Maret 14). Retrieved Februari 20, 2020, from Dr.Rasto,M.Pd (Universitas Pendidikan Indonesia): asto.staf.upi.edu/2016/03/14/fa ktor-faktor-yang-mempengaruhimotivasi/\#_ftn2

Fatimah, S. F. (2015). Pengaruh Komptensi Sumber Daya Manusia Terhadap Kinerja Karyawan (Studi Pada Kantor Pusat PT Perkebunan Nusantara IV (PERSERO) Medan). Medan: Repositori Institusi Universitas Sumatera Utara.

H. M. (2012). Manajemen Sumber Daya Manusia, Edisi Revisi. Jakarta: Bumi Aksara.

Hamid, M. S. (2015). IDENTIFIKASI KOMPETENSI KARYAWAN YANG MEMPENGARUHI PENCAPAIAN KINERJA BIDANG PRODUKSI DI PT. INDUSTRI SANDANG NUSANTARA (PERSERO) DENGAN PEMBERIAN. Bandung: Universitas Widyatama .

Handoko, T. (2011). Manajemen Personalia dan Sumber Daya Manusia. Yogyakarta: BPFE.

Hapsari, W. P. (2017, Juli 1). Retrieved Januari 25, 2020, from dictio: https://www.dictio.id/t/faktorfaktor-apa-saja-yangmempengaruhi-kepuasankerja/8697

Hasibuan, M. S. (2011). Manajemen Sumber Daya Manusia. Jakarta: Bumi Akasara.
Jufri, Z. K. (2018). Kompetensi Sumber Daya Manusia di Kantor Ssistem Administrasi Manunggal Satu Atap (SAMSAT) Wilayah Gowa. eprints unm, 1-9.

Maharani, A. (2013). Hubungan Budaya Kerja Karyawan Dengan Produktivitas Kerja Karyawan PT. Bank Tabungan Negara (Persero) Tbk kantor Cabang Syariah Malang. Malang: Etheses Of Maulana Malik Ibrahim State Islamic University.

Marwansyah. (2016). Manajemen Sumber Daya Manusia Edisi Duac Cetakan Keempat. Bandung: CV Alfabeta.

Moeheriono. (2010). Pengukuran Kinerja Berbasis Kompetensi-Competency Based Human Resources Management. Bogor: Ghalia Indonesia.

Mohammad, R. (2015). 24(1).

Mulyadi, Johny, \& Setiawan. (2012). Sistem Perencanaan dan Pengendalian Manajemen, Edisi Kedua, Cetakan Pertama. Yogyakarta: Penerbit Aditya Media.

Nurasiah Syarifuddin, S., Semmaila, B., \& Husain, A. (2019, Juli). Pengaruh Gaya Kepemimpinan, Motivasi Kerja dan Kompetensi Terhadap Kinerja Pegawai (Studi Pada Badan Pengelolaan Keuangan Kab.Gowa). Jurnal Paradox, II(3), 107-117.

Nurfitriana, d. (2010). Teknologi Informasi,sistem pengukuran kinerja, dan sistem penghargaan sebagai pemoderasi hubungan antara total quality management dengan kinerja manajerial. Akuntabilitas, 5.

Nurhadijah. (2017). Studi tentang Budaya Kerja Pegawai Sekolah Menengah Kejuruan Negeri 1 
Penajam Paser Utara. ejournal Administrasi Negara, V(1).

Riadi, M. (2017, Oktober 24). Retrieved Februari 10, 2020, from Kajian Pustaka: https://www.kajianpustaka.com/ 2017/10/dimensi-faktor-danmembangun-komitmenorganisasi.html

Satuti, W. S. (2019, Agustus 8). Budaya Kerja: Pengertian, Tingkatan, Ciri, dan Jenis. Retrieved Maret 10, 2020, from Jojonomic.

Seesar, Y. (2010). Perbandingan Implementasi Insourching, Consourching dan Outsouching Dalam Pengembangan Sistem Informasi. Bandung: PT Remaja Rosdakarya.

Seputar Pengetahuan. (2017, 12 01). Retrieved 02 18, 2020, from Portal Media Pengetahuan Online: https://www.seputarpengetahua n.co.id/2017/12/pengertiankomitmen-organisasi-manfaatbentuk-indikator-faktor-yangmempengaruhi.html

Sudarmanto. (2009). Kinerja dan Pengembangan Kompetensi SDM. Yogyakarta: Pustaka Pelajar.

Sugiyono. (2017). Metode Penelitian Kuantitatif, Kualitatif, dan R\&D. Bandung: CV Alfabeta.

Sukamadinata. (2018). Metode Penelitian Pendidikan. Bandung: PT Remaja Rosdakarya.

Sutarman. (2009, Oktober 16-17). Pengaruh TQM terhadap Kinerja Manajerial Dengan Sistem Pengukuran Kinerja dan Sistem Penghargaan sebagai Variabel Moderating (studi empiris pada Hotel di Indonesia).

Syafi'i A. (2005). Metodologi Penelitian Pendidikan. Surabaya: el KAP.
Wibowo. (2012). Manajemen Kinerja. Jakarta: PT Raja Grafindo Persada.

Wibowo. (2016). Manajemen Kinerja Edisi Kelima. Jakarta: PT Rajagrafindo Persada.

www.perpuskampus.com.

(2016, Oktober 30). Pengertian dan Indikator Kinerja. Retrieved from https://perpuskampus.com/peng ertian-dan-indikator-kinerja/ 